\title{
REPRODUCTIVE PERFORMANCE, OVARIAN VASCULARIZATION, FOLLICULAR DYNAMICS, AND BLOOD HORMONES AFTER ESTROUS SYNCHRONIZATION OF SA'IDI GOATS
}

\author{
M.A. Abdel-Ghani ${ }^{1 *}$, M. Hayder ${ }^{2}$,N.S. Abou-Khalil ${ }^{3}$, D.R. Derar ${ }^{1}$, F.F. AbouAmmou ${ }^{2}$, \\ M.H. El-Shafie ${ }^{2}$, T.M.M. Abdel-khalek ${ }^{2}$, H. Hamdon ${ }^{4}$ \\ 1- Department of Theriogenology, Faculty of Veterinary Medicine, Assuit University, Assuit, 71526, \\ Egypt, 2-Animal Production Research Institute,Agriculture Research Center, Dokki, Giza,12311, \\ Egypt, 3- Department of Medical Physiology, Faculty of Medicine, Assiut University, Assuit, 71526, \\ Egypt, 4- Animal Production Dept., Faculty of Agriculture, Assiut University, New Valley Branch, El \\ kharga, New Valley, 3201, Egypt \\ *Correspondence: M.A.Abdel-Ghani(e-mail: mohammed_ali76@hotmail.com)
}

\section{SUMMARY}

The objectives were to determine the effects of estrus synchronization on reproductive performanceof Sa'idi goats, and to examine the relationship between follicular blood flow (FBF) of ovulatory follicle and serum concentrations of progesterone P4, Estradiol-17 $\beta$ (E2) and nitric oxide (NO). Group 1 (sa'idi goats) was received an intravaginal sponge for $14 d$ (LT group), and was injected with 500 IU PMSG at the time of sponge removal. Group 2 (sa'idi goats) was received an intravaginal sponge for $5 \mathrm{~d}$ (ST group), and was injected with $500 \mathrm{IU}$ PMS and $2.5 \mathrm{mg}$ of Dinoprostat the time of sponge removal. Arbitrary blood flow scalewas used to assess the FBF in color Doppler images. There wasno difference observed between the ST and LTgroups in terms of reproductive parameters. The multiple kidding rates were different $(P<0.05)$, being $61.5 \%$ LT group and $46.2 \% S T$ group respectively. The Arbitrary blood flow was increased with the increase in the diameter of ovarian follicles. The ST group had greater $(P<0.05)$ blood flow scores than LT group on Day 0.The P4 concentrations were similar $(P>0.05)$ between the two groups. On Day 2, 3 and 4, concentrations of E2 were greater in ST group $(P<0.05)$ than in LT group. The NO concentration tended to be differ $(P$ $<0.05)$ in LT group before sponge withdrawal compared with ST group. In conclusion, there is a positive relationship between $E 2$ and $N O$, butE2 and NO concentrations were closely related to the $F B F$.

Keywords: color doppler ultrasonography, estrous synchronization, follicular blood flow, reproductive performance

\section{INTRODUCTION}

Estrous synchronization, particularly in ruminants, is a valuable management tool that has been successfully employed to improve the production of milk and meat (Hashemi et al., 2006). In addition, as the popularity of goat production continues to increase, pressure to develop efficient and cost-effective methods for estrus synchronization in goats becomes more important. Therefore, with estrous synchronization, producers are able to more efficiently use reproductive biotechnologies for reproductive management, including AI and embryo transfer, so that genetic material is more easily obtained or transferred domestically and internationally (Whitley and Jackson, 2004).

Transrectal color Doppler ultrasonography is a useful, and noninvasive technique that has been successfully used for evaluating ovarian vascular function, allowing a visual observation of the blood flow in the wall of follicles (Brannstrom et al., 1998) and corpus luteum (Acosta et al., 2003). This image has facilitated haemodynamic studies and reproducible measurements (Acosta et al., 2002). The use of color Doppler ultrasonography to investigate the ovarian responses after hormonal stimulation has recently been studied in sheep (El-sherry et al., 2013), horses (Witt et al., 2012) and cows (Matsui and Miyamoto, 2009). In addition, follicle blood flow assessment by Doppler ultrasonography has been used in mares to study the role of follicle vascularity in maturity of the preovulatory follicle after hCG treatment (Gastal et al., 2006 and Ginther et al., 2007) and oocyte maturity (Ginther et al., 2007).

Moreover, nitric oxide (NO) is a potent vasodilator agent that is involved in folliculogenesis and ovulation (Tamanini et al., 2003) and vasculature, capillary area density, and capillary number density were positively correlated with NO production (Moonmanee et al., 2013). In addition, NO stimulates the synthesis of both PGE and PGF $2 \alpha$ that cause inflammation in the preovulatory follicle and induce rupture (Faletti et al., 1999) with other 
locally produced substances, growth factors and cytokines (Tamanini et al., 2003)

The objectives of the current study was to compare the changes in reproductive performance, sex hormones, follicular dynamics and blood flow (BF) within the ovulatory follicle after short-term and long-term progesterone based synchronization protocols of Saidi goats.

\section{MATERIALS AND METHODS}

\section{Animals and experimental design:}

Adult female goats $(\mathrm{n}=30)$ with almost similar age (1.5-3 years) and weight $(20-23 \mathrm{Kg})$ were selected from the lot maintained at Mallawi Animal Production Research Station, El-Minia, Egypt, (latitude $28^{\circ} 07^{\prime} \mathrm{N}$ and $30^{\circ} 33^{\prime} \mathrm{E}$ ) during the first three weeks of October (Autumn). The Sa'idi goats are a local Egyptian breed found in the Upper Egypt. The animals are kept mainly for meat production. The goats were maintained graze on in pens during all the day. Water was available ad libitum. The management of the goats did not change throughout the experimental period. The bucks were separated from goats. The goats were randomly divided into two equal groups, and were registered by numbering on their ears.Group 1 (Long-term progestagen treatment-PMSG): the animals were received an intravaginal Progestagen impregnated sponge (40 $\mathrm{mg}$ fluorogestone acetate, GFA, Chronogest ${ }^{\circledR}$ Intervet, International, boxmeer, Netherland) for 14 days, and were injected with 500 IU PMSG (Folligon, Intervet) at the time of sponge removal.Group 2 (Short-term progestagen treatment-PMSGPGF2 $\alpha$ ): the animals were received an intravaginal Progestagen impregnated sponge for 5 days. At the time of sponge removal, $500 \mathrm{IU}$ PMSG and $2.5 \mathrm{mg}$ of Dinoprost (Lutalyse, Pfizer manufacturing, Purts, Belgium) were injected intramuscularly.

Applications of hormones used for the estrous synchronization were made between 18:00 and 19:30 $\mathrm{h}$ in all groups. Starting from the first hour of removal of the intravaginal sponges in all groups, the occurrence of behavioral estrus signs was monitored every four $\mathrm{h}$ interval and for five $\mathrm{d}$ using teaser bucks ( $\mathrm{n}=$ 6 ). The goats were considered to be in estrus only if they stood while being mounted by the bucks (standing behavior). A buck was introduced in the herd during the experiment for breeding purpose. The mating was scheduled every $12 \mathrm{~h}$ until does refuse to be mounted by bucks. The mated goats were recorded and kept under close observation to detect the number of abortions until parturition. Duration of estrus was defined as the interval between the onset and the end of estrus signs. The end of estrus was the time when the doe refuse to be further mounted. The day of Progestagen withdrawal considered as Day 0.
The reproductive parameters were calculated following the treatment according to Karaca et al. (2010) and Sim̃os et al. (2006) were as follows:

* Onset of estrus (interval from sponge's removal to time of first estrus identification).

* Estrus response (number of goats showing oestrus/total number of goats treated in each group X 100).

* Onset of follicular wave: First observation of at least one follicle $\geq 3 \mathrm{~mm}$ diameter, followed by a growing follicular wave resulting in a follicle with a minimal diameter of $5 \mathrm{~mm}$.

* Day of maximum follicular diameter: The first day when the dominant follicle reached its maximum diameter $(>5 \mathrm{~mm})$.

* End of follicular wave: The day when the number of follicles $<3 \mathrm{~mm}$ increased and the number of follicles $\geq 3 \mathrm{~mm}$ decreased by the same proportion.

* Duration of wave: Interval between the onset and the end of a follicular wave.

* Pregnancy rate (number of pregnant goats/ number of mated goats in each group X 100).

* Abortion rate (number of aborted goats/ number of pregnant goats in each group X 100).

* Kidding rate (number of kidding goats/ number of pregnant goats in each group X 100).

* Multiple kidding rates (number of goats kidding twin or triplet/number of kidding goats in each group X 100).

* Litter size (number of total kids/number of kidding goats kidded in each group).

\section{Doppler ultrasound monitoring of follicular development:}

Ultrasound scanning was performed by the same operator every $24 \mathrm{~h}$ until ovulation using a Doppler ultrasound scanner (Mylab30, Piemedical, Netherlands), equipped with a 6-8 $\mathrm{MHz}$ endorectal linear probe (Lv513). Examinations were conducted on the standing goat. The urinary bladder was used as a guide to find the uterine horn. The probe was rotated laterally $90^{\circ}$ clockwise and $180^{\circ}$ anticlockwise to scan the ovaries and genitalia. The size and number of follicles larger was detected and profiled by retrospective evaluation of ovarian sketches that provided topographical and the diameter changes for each follicle. The follicular dynamics and ovulation rate were recorded. Following morphological evaluation of the ovarian findings, the power flow mode of the ultrasound scanner was activated for blood flow mapping. Color signals were used to evaluate the blood flow around the entire perimeter of the follicle.

An arbitrary-scale was used to assess the follicular blood flow in Doppler image. The scale was scored accordingly to Oliveira et al. (2014): (0) non-detectable, (1) small, (2) moderate, (3) intense blood flow (Figure1). 

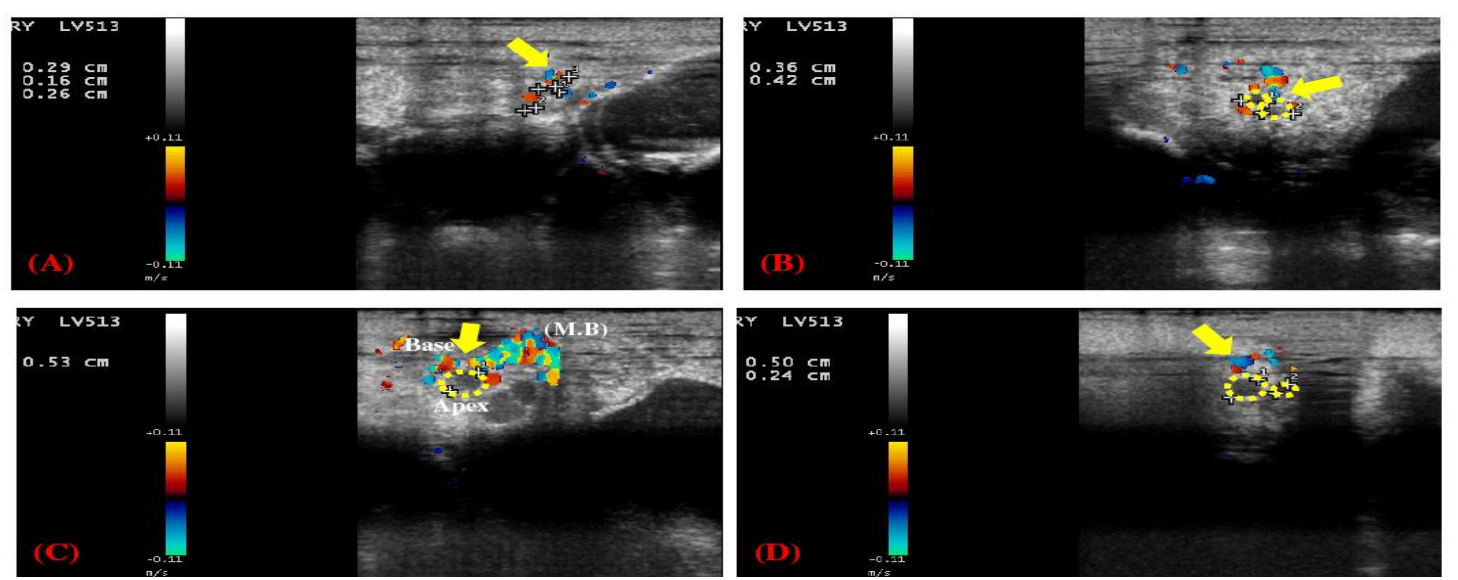

Fig. 1. Color Doppler images of arbitrary blood flow (yellow arrows) and follicular diameter. (A) Showing the growing follicle and (B) showing selected follicle. (C) Showing a prominent changes in the regional blood flow of the follicle with a marked increase of the flow to the base of the follicle and a concomitant decrease of blood flow to the apex (the base is ischemic) before ovulation; M. B represented the main blood branch that nourish the follicle. (D) Showing an insufficient vascular supply that could act as the trigger that leads to follicular atresia

\section{Blood collection and hormonal determination}

The blood samples were collected via jugular venipuncture at the time of sponge insertion, then every three days till the time of sponge removal (Day 0). At Day 0, the blood samples were collected daily for four $\mathrm{d}$ just after each Doppler scan. The blood samples were allowed to clot at room temperaturethen centrifuged within half an hour after collection and were stored at $-20^{\circ} \mathrm{C}$. The hormones were assayed in blood serum. Circulating concentrations of P4 and E2 were determined by ELISA kits (BioChek, Inc., Foster City, CA 94404, USA). The lowest detectable level of P4 in this test is $0.05 \mathrm{ng} / \mathrm{ml}$ and $10 \mathrm{pg} / \mathrm{ml}$ for $\mathrm{E} 2$.The $\mathrm{NO}$ was analyzed by Colorimetric Determination of Nitrite (Biodiagnostic, catalog No. TA2532, Egypt). The final products of $\mathrm{NO}$ in vivo are nitrite $\left(\mathrm{NO}_{2}\right)$ and nitrate $\left(\mathrm{NO}_{3}\right)$. There is an exogenous source of $\mathrm{NO} 3$ from the diet, so the index of $\mathrm{NO}$ production is the $\mathrm{NO}_{2}$. The biodiagnostic nitrite assay kit provides an accurate and convenient method for measurement of endogenous nitrite concentration as indicator of endogenous NO production in biological fluids.

\section{Statistical analysis:}

All data were expressed as mean $\pm \mathrm{SD}$. The comparisons of mean values were performed by Kruskal-Wallis ANOVA on Ranks followed by Dunn's multiple comparisons. All statistics were calculated with the help of either JMP v5.0.1 (SAS campus drive, Cary, NC, USA) or Graphpad Prism v5 software (Graphpad Software, Inc., San Diego, CA). Differences of $\mathrm{P}<0.05$ were regarded as significant.

\section{RESULTS}

\section{Reproductive performance and follicular growth:}

The reproductive performances of the goats were presented in Table (1). Estrus was detected in $86.7 \%$ and $93.3 \%$ of the does for the LT and ST groups, respectively. The onset and end of estrous symptoms were $25.3 \pm 10.1$ to $65.5 \pm 14.4$, and $25.0 \pm 8.9$ to $76.5 \pm 17.3 \mathrm{~h}$, for the LT and ST groups, respectively $(\mathrm{P}>0.05)$. The duration of heat in LT group (Table 1) was shorter $(\mathrm{P}>0.05)$ than in that ST group.The percentage of goats that showed estrus $48 \mathrm{~h}$ following the sponge withdrawal in LT group was $100 \%$, however, $100 \%$ of the goats showed estrus $32 \mathrm{~h}$ following the sponge withdrawal in ST group (Figure 2).

The diameter of recruited follicles was $2.5 \pm 0.3 \mathrm{~mm}$ for LT group and $2.8 \pm 0.2 \mathrm{~mm}$ for ST group (Figure 3). In LT group, the maximum follicular diameter was $6.0 \pm 0.4 \mathrm{~mm}$ and $6.0 \pm 0.5$ $\mathrm{mm}$ in ST group. There was no difference $(P>0.05)$ between two the groups in the size of recruited and ovulatory follicles.

The multiple kidding rates were different $(\mathrm{P}<0.05)$; being higher in LT group than ST group. However, the pregnancy rate, kidding rate and litter size were similar $(\mathrm{P}>0.05)$ (Table 2).

\section{Blood flow:}

Arbitrary blood flow scores were set out in figure (4). The Arbitrary blood flow was increased with the increase in the diameter of the follicles in both groups of the studied goats. The STgroup had greater $(\mathrm{P}<0.05)$ blood flow scores than LT group on Day 0, however, There was no difference $(\mathrm{P}>0.05)$ between two the groups after day 0 . 
Table 1. Reproductive performance (mean \pm SD) of Sa'idi goats after long-term (LT group) and short-term (ST group) progesterone treatment

\begin{tabular}{lcc}
\hline Reproductive parameters & LT group & ST group \\
\hline Estrus response (\%) & $86.7 \%$ & $93.3 \%$ \\
Onset of heat (h) & $25.3 \pm 10.1$ & $25.0 \pm 8.9$ \\
End of heat (h) & $65.5 \pm 14.4$ & $76.5 \pm 17.3$ \\
Duration of heat (h) & $40.7 \pm 15.0$ & $52.3 \pm 18.7$ \\
Onset of the wave (d) & $0.4 \pm 0.5$ & $0.3 \pm 0.5$ \\
First day of maximum follicular diameter & $4.1 \pm 0.3$ & $4.5 \pm 0.5$ \\
Growing phase (d) & $3.8 \pm 0.5$ & $4.2 \pm 0.9$ \\
Maximum follicular diameter (mm) & $6.2 \pm 0.5$ & $6.0 \pm 0.4$ \\
End of wave (d) & $4.9 \pm 0.4$ & $5.1 \pm 0.4$ \\
Length of wave (d) & $4.5 \pm 0.8$ & $4.8 \pm 0.4$ \\
\hline
\end{tabular}

Table 2. The pregnancy rate, abortion rate, kidding rate, multiple kidding rate and litter sizes of Sa'idi goats after long-term (LT group)and short-term (ST group)progesterone treatment

\begin{tabular}{cccccc}
\hline Treatment & $\begin{array}{c}\text { Pregnancy } \\
\text { rate }\end{array}$ & $\begin{array}{c}\text { Abortion } \\
\text { rate }\end{array}$ & Kidding rate & $\begin{array}{c}\text { Multiple } \\
\text { kidding rate }\end{array}$ & Litter size \\
\hline LT group no. & $8 / 13$ & $1 / 8$ & $7 / 8$ & $7 / 7$ & $22 / 7$ \\
$\%$ & $(61.5 \%)$ & $(12.5 \%)^{\mathrm{a}}$ & $(87.5 \%)$ & $(100 \%)^{\mathrm{a}}$ & $(3.1)$ \\
ST group no. & $6 / 13$ & $0 / 6$ & $6 / 6$ & $3 / 6$ & $11 / 6$ \\
$\%$ & $(46.2 \%)$ & $(0.0 \%)^{\mathrm{b}}$ & $(100 \%)$ & $(50 \%)^{\mathrm{b}}$ & $(1.8)$ \\
\hline
\end{tabular}

${ }^{-b}$ within a column, means without a common superscript differed $(P<0.05)$.

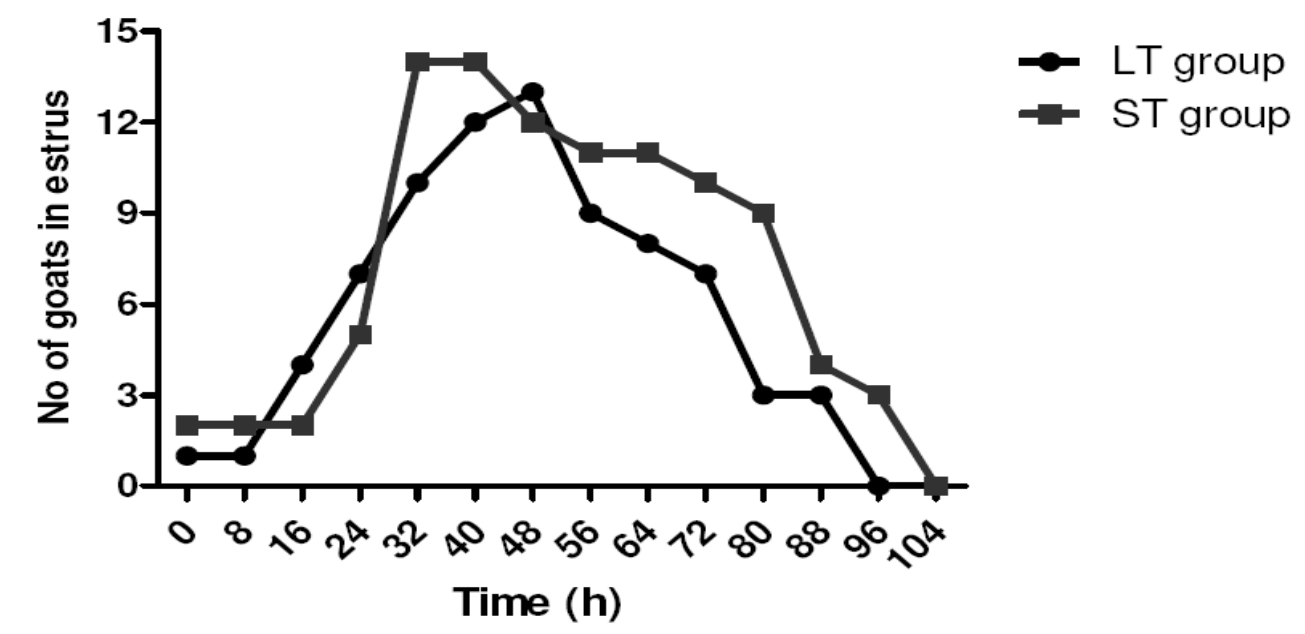

Fig. 2. Distribution of the onset of estrus after long-term progesterone treatment (LT group) and short-term progesterone treatment (ST group) of sa'idi goats.

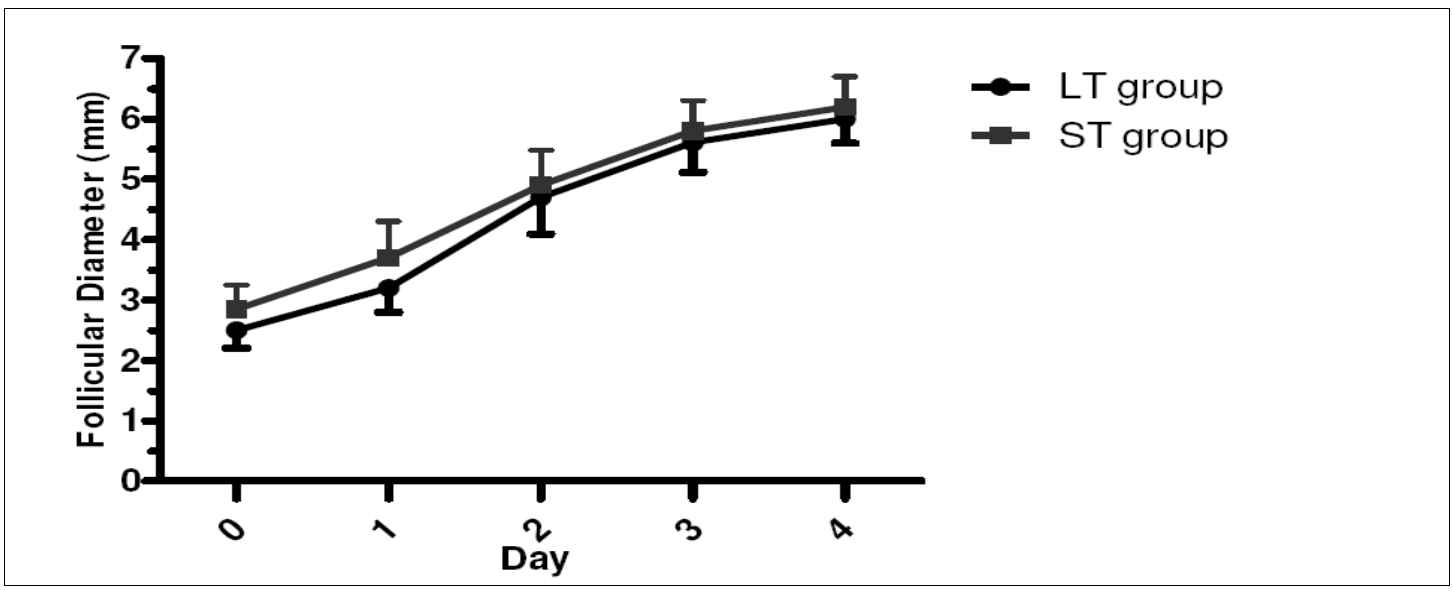

Fig. 3. Mean \pm SD. Changes in diameter of the ovulatory follicular (mean \pm SD) induced long-term progesterone treatment (LT group) or short-term progesterone treatment (ST group) of Egyptian goats. 
Blood serum hormones concentration:

The P4 concentrations in blood serum were almost similar $(\mathrm{P}>0.05)$ in the two groups (Figure 5). On Day 2, 3, and 4 the concentrations of estradiol-17 $\beta$ (E2) were greater in ST group $(\mathrm{P}<0.05)$ than that in LT group (Figure 6). The E2 concentrations were almost similar $(\mathrm{P}>0.05)$ in the two groups before sponge withdrawal. In contrast, the concentration of the NO tended to differ $(\mathrm{P}<0.05)$ in LT group before sponge withdrawal compared with ST group (Figure 7). However, there was no difference $(\mathrm{P}>0.05)$ between the two groups in the concentrations of the NO after sponge withdrawal.

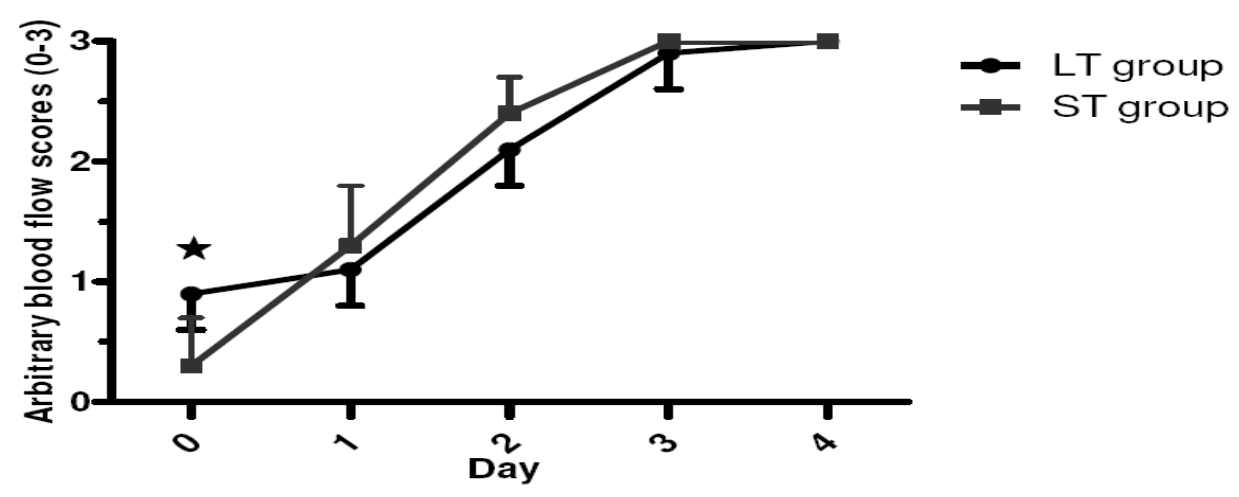

Fig. 4. scored scale (mean \pm SD) of ovarian blood flow of sa'idi goats during heat and the four subsequent days. Differences $(P<0.05)$ between the two groups were denoted by $\star$.

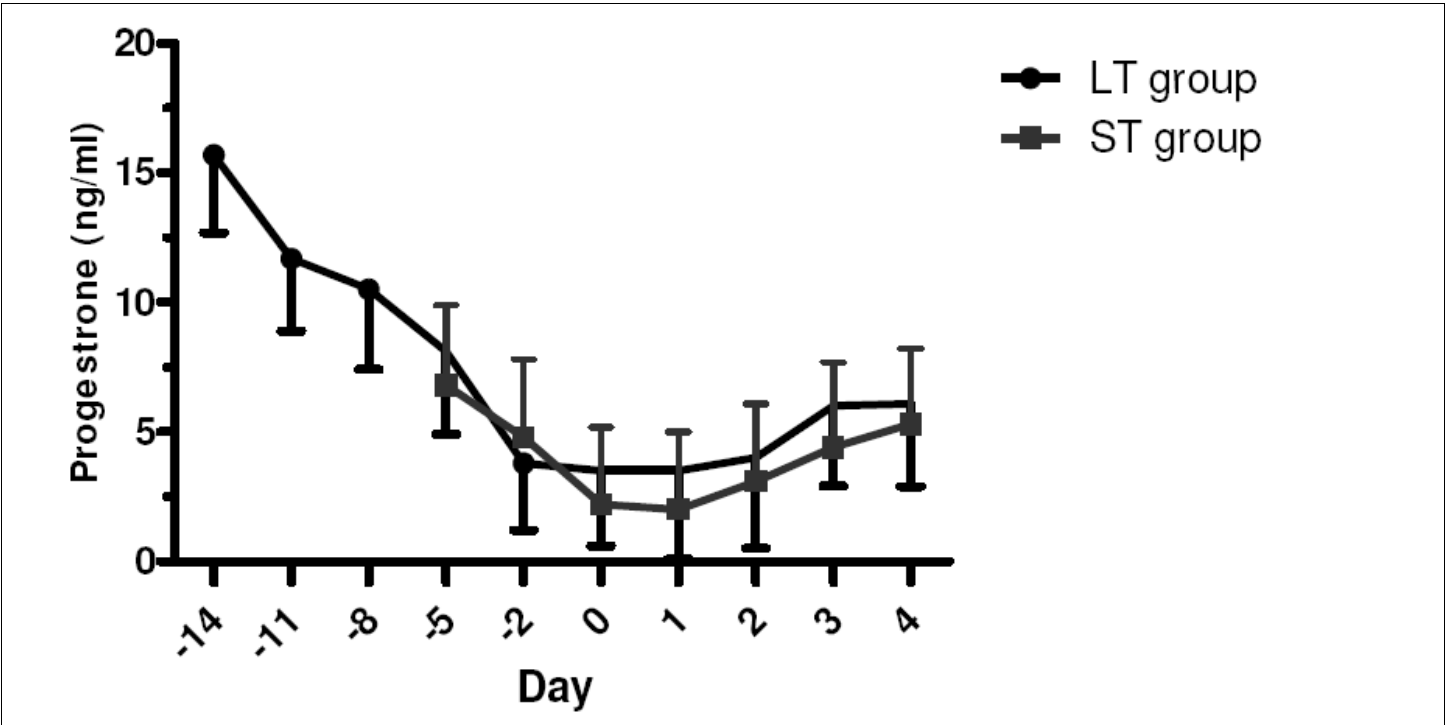

Fig. 5. Changes in plasma progesterone $(P 4)$ concentration. Differences $(P<0.05)$ between the two groups were denoted by $\star$.

\section{DISCUSSION}

In the present study, no difference was observed between the ST and LT treatments combined with PMSG in the studied reproductive parameters (Table 1). The onset of heat in both groups was similar to those obtained in goats by Freitas et al., (1997) $(27.8 \pm 5.0 \mathrm{~h})$, Motlomelo et al. (2002) (30.9 $\pm 0.4 \mathrm{~h})$ and Romano (2004) (32.9 \pm 9.7 h). However, the onset of heat was longer than those of Dogan et al. (2005) (18.0 $\pm 1.9 \mathrm{~h})$, who used 500 IU PMSG $2 \mathrm{~d}$ before the sponges removal, but were shorter than those $(49.7 \pm 15.5 \mathrm{~h})$ of Fonseca et al. (2005), who used 200 IU PMSG $24 \mathrm{~h}$ before sponge removal. These differences may be associated with the dose of PMSG used in the present study. The PMSGis known to reduce the interval between sponge removal and onset of estrus (Greyling et al., 1985). Regueiro et al. (1999) showed that the use of 500 IU PMSG decreased the interval to estrus onset in Nubian, Saanen and cross-breed goats. However, (Ustuner et al., 2007) reported that there was no significant effect of the type of progestagen sponges or time of PMSG administration on the time to estrus onset in ewes. On Day 2, 3, and 4 the concentrations of E2 were significantly higher in ST group than in LT group that may give explanation for the shorter duration of heat in LT group $(40.7 \pm 15.0 \mathrm{~h})$ than in ST group. 


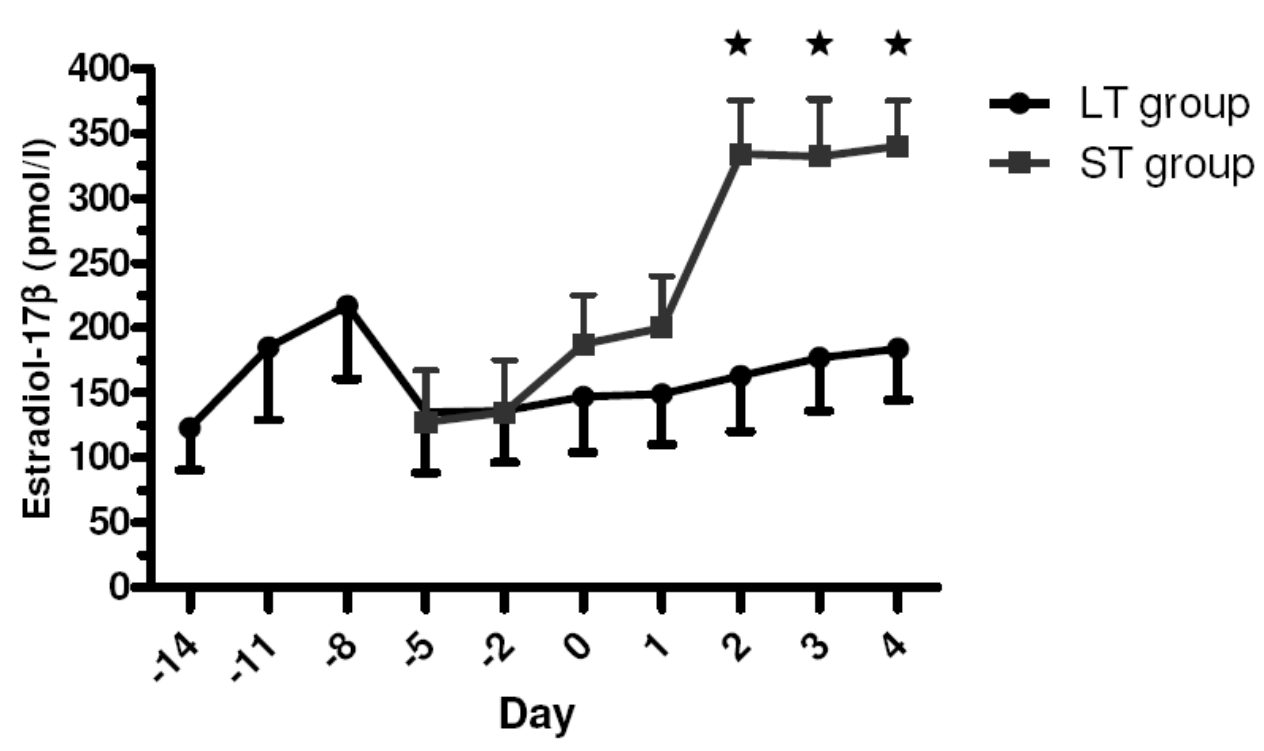

Fig. 6. Changes in plasma estradiol-17 $($ mean \pm SD) in long (LT) and short (ST) progesterone treated sa'idi goats. Differences $(\mathrm{P}<0.05)$ between the two groups were denoted by $\star$.

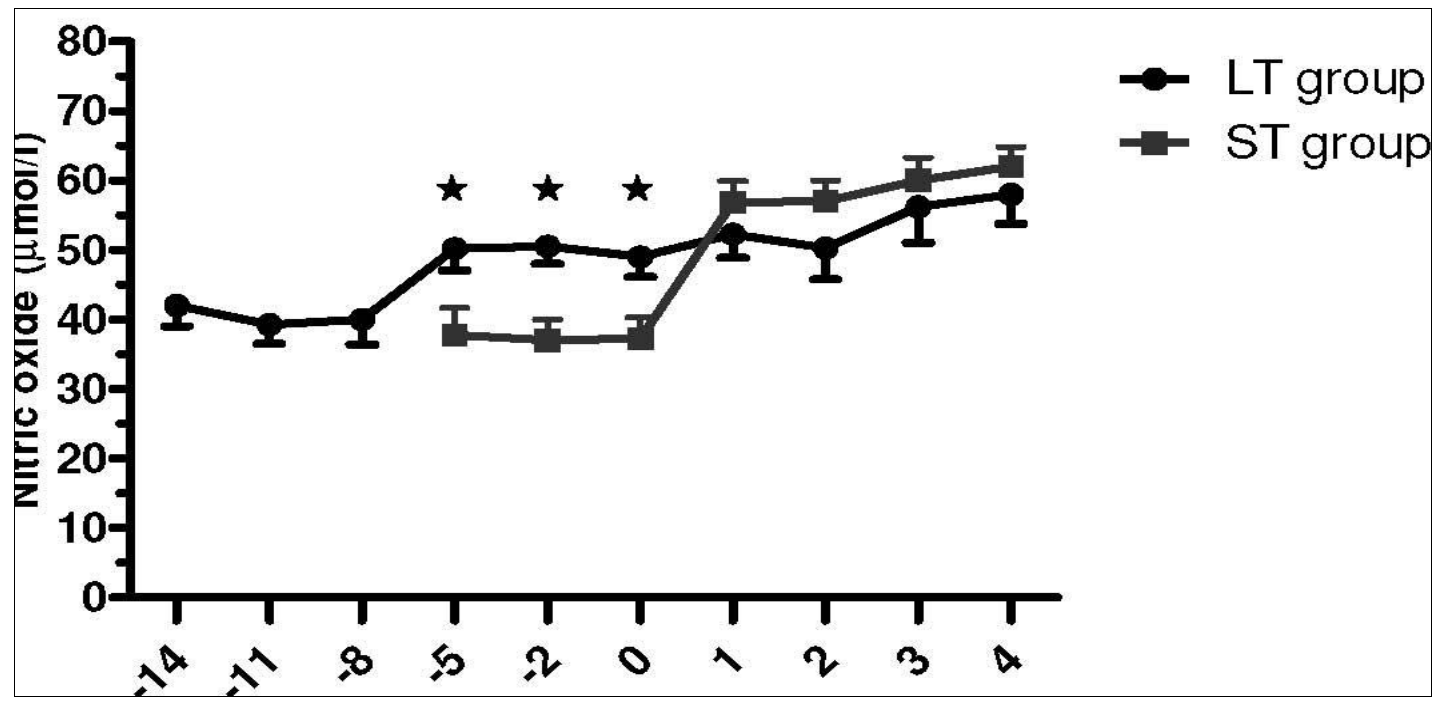

Fig. 7. Changes in plasma nitric oxide (mean \pm SD) in long (LT) and short (ST) progesterone treated sa'idi goats. Differences $(P<0.05)$ between the two groups were denoted by $\downarrow$.

The results of LT progestagen treatment did not improve reproductive performance of goats, as it has been reported in ewes (Karaca et al., 2009). The reason for this variation is not clear; it may be associated with the PMSG used at the time of sponge removal in goats in the onset of breeding season. It has been reported that the administration of PMSG when progestagen treatment was terminated, could compensate the deleterious effect of long-term progestagen treatment on follicular dynamics in cyclic ewes (Noël et al., 1994). In addition, Barrett et al. (2004) revealed that, in anestrus ewes, 500 IU of PMSG given at the end of a $12 \mathrm{~d}$ treatment with progestogen-impregnated intravaginal sponge limited effects on the dynamics of ovarian follicular waves. The abortion rate observed in the present study was $27.9 \%$ for LT group. In the aborted goats, no symptoms of infectious diseases were observed; this rate was comparable to the incidence of fetal loss $(3-38 \%)$ that was reported in the different goat herds by Engeland (1998).

Changes of vascularization and expression of some regulators, including angiogenic factors, are associated with follicular growth and/or atresia. Vascular network around developing follicles may be rate limiting for the selection of the dominant follicle that is destined to ovulate. In the present study, the blood flow increased from Days 0 to Day 5 in both ST and LT groups of goats as well as the follicular diameter, and 
the concentrations of NO and E2 were increased with the increase of blood flow. Therefore, the marked increase in ovarian blood flow was associated with the increase of NO, E2 and follicular growth. The NO is a potent vasodilator agent that is involved in folliculogenesis and ovulation (Tamanini et al., 2003). The healthy follicles have a greater ability to produce E2 during a period of relatively low serum gonadotropin concentration (Grazul-Bilska et al., 2007). The E2 is recognized as the follicular growth, differentiation, and survival factor, which enhances aromatase activity, promotes expression of $\mathrm{LH}$ receptors, and increases sensitivity of granulosa cells to FSH and LH (Quirk et al., 2004). In addition, the follicular estradiol enhanced NO production, and may cause a rapid dilation of blood vessels by activating angiogenic factor such as endothelial nitric oxide synthase (eNOS) (El-Sherry et al., 2013).

The eNOS mRNA was detected in both theca and granulosa cell layers of ruminant species (Grazul-Bilska et al., 2007). However, the protein was immunolocalized only in the theca and exclusively in the blood vessels of developing preovulatory and postovulatory follicles (Tessaro et al., 2011). The eNOS is involved in follicular and luteal angiogenesis through the production of nitric oxide (NO) (Grazul-Bilska et al., 2006). On a cellular level, successful development of ovulatory follicles requires both proliferation and differentiation of follicular cells (Feranil et al., 2004). Such high proliferation of granulosa and theca cells of follicles may be closely associated with increased NO production. Thus, the expressions of eNOS in the cal layers were greater in the healthy follicle than in the atretic follicle (Moonmanee et al., 2013). Therefore, the higher NO concentration was coincidental with the increase in follicular diameter and reached the maximum level at the time of ovulation as observed in our study. Furthermore, the NO is a potent vasodilator agent (Tamanini et al., 2003) and vasculature, capillary area density, and capillary number density were positively correlated with NO production (Moonmanee et al., 2013). Therefore, the increase in Blood flow cloud have been due to high concentration of NO that associated with the increase in follicular diameter. Moreover, because the granulosa layer has no blood vessels (Redmer et al., 1996), the eNOS were not detected in the granulosa layer of all follicles (Moonmanee et al., 2013) that may give explanation for why the blood flow was absent or reduced in recruited follicle and before theca layer formation.

Increased the follicular vascularization and permeability of blood vessels are known to allow a greater supply of growth factors, gonadotropins, and dissolved oxygen important to the growth of follicles resulted in follicular progression, follicular fluid production and antrum formation (Van den Hurk and Zhao, 2005). In turn, insufficient vascular supply could act as the trigger that leads to follicular atresia (Augustin et al., 2001). Thus, vascular supply or blood flow was significantly increased after selection of the goat dominant follicle and the vascularization of the follicular wall were greater in follicles that subsequently developed into antral follicle. Moreover, there are prominent changes in the regional blood flow of the follicle with a marked increase in the blood flow to the base of the follicle and a concomitant decrease of blood flow to the apex before ovulation. Similarly, El-Sherry et al. (2013) investigated the regional changes of blood flow in the ewe follicle, they demonstrated that blood flow is localized at the bottom of the follicle while the base is ischemic. Taking together, the NO has a role in maintaining vascularization during follicular growth and selection of the follicles for complete ovulation.

In conclusion, the estrus synchronization using LT progestagen did not have a positive impact on thereproductive performance of the Sa'idi goats, and could be replaced with ST progestagen at the beginning of breeding season. In addition, there is a positive relationship between E2 and NO, and E2. The NO concentrations were closely related to the FBF.

\section{ACKNOWLEDGMENT}

This study was kindly supported by project of Introducing Improved Genotypes and better managements to increase small ruminant roles in conventional Egyptian farm as an investment or income pattern. Grant No: 416 B

\section{REFERENCES}

Acosta, T.J., Hayashi, K.G., Ohtani, M., Miyamoto, A., 2003. Local changes in blood flow within the preovulatory follicle wall and early corpus luteum in cows. Reproduction 125, 759-767.

Acosta, T.J., Yoshizawa, N., Ohtani, M., Miyamoto, A.,2002. Local changesin blood flow within the early and midcycle corpus luteum afterprostaglandin $\mathrm{F} 2$ _ injection in the cow. BiolReprod. 66, 651-658.

Augustin, H.G.,Iruela-Arispe, M.L., Rogers, P.A.W., Smith, S.K., 2001.Vascular morphogenesis in the female reproductive system.Birkhauser Boston, New York 109130.

Barrett, D.M.W., Bartlewski, P.M., BatistaArteaga, M., Symington, A., Rawlings, N.C., 2004. Ultrasound and endocrine evaluation of the ovarian response to a single dose of 500 IU of eCG following a 12-day treatment with 
progestogen-releasing intravaginal sponges in the breeding and nonbreeding seasons in ewes. Theriogenology 61, 311-327

Brannstrom, M., Zackrisson, U., Hagstrom, H., Josefsson, B., Hellberg, P.,Granberg, S., Collins, W., Bourne, T.,1998.Preovulatory changes ofblood flow in different regions of the human follicle. Fertil.Steril.69, 435-442.

Dogan, I., Konyalı, A., Tolu, C., Yurdabak, S., 2008. Different estrous induction protocols du-ring the transition period in lactating Turkish Saanen does following AI. Acta Vet.Beograd. 58, 259-266.

EL-Sherry, T.M., Derar, R. Bakry, R., 2013. Changes in blood flow in ovine follicles and serumconcentration of estradiol 17 beta (E2) and nitric oxide (NO)around the time of ovulation in Ossimi ewes Anim. Reprod. Sci. $138,188-193$.

Engeland, I.V., Waldeland, H., Andresen, Ø.,Løken, T., Björkman, C., IngeBjerkås, I., 1998. Foetal loss in dairy goats: an epidemiological study in 22 herds. Smal. Rum. Res. 30, 37-48.

Faletti, A., Perez Martinez, S., Perotti, C., de Gimeno, M.A., 1999. Activityof ovarian nitric oxide synthase (NOs) during ovulatory process in the rat: relationship with prostaglandins (PGs) production. Nitric Oxide3, 340-347.

Feranil, J.B., Isobe, N., Nakao,T., 2004.Cell proliferation in the atretic follicles of buffalo and cattle ovary. Reprod. Domest. Ani., 39, 405-409.

Fonseca, J.F., Bruschi, J.H., Santos, I.C.C., Viana, J.H.M., Magalhães, A.C.M., 2005. Induction of estrus in non-lactating dairy goats with different estrous synchrony protocols Anim. Reprod. Sci. 85, 117-124.

Freitas, V.J.F., Baril, G., Saumande, J., 1997. Estrus synchronization in dairy goats: use of fluorogestone acetate vaginal sponges or norgestomet ear implants. Anim. Reprod. Sci. 46, 237-244

Gastal, E.L., Gastal, M.O., Ginther, O.J., 2006. Relationships of changes in B-mode echotexture and colour-Doppler signals in the wall of the preovulatory follicle to changes in systemic oestradiol concentrations and the effects of human chorionic gonadotrophin in mares. Reproduction 131, 699-709.

Ginther, O.J., Gastal, E.L., Gastal, M.O., Siddiqui, M.A.R., Beg, M.A., 2007. Relationship of follicle versus oocyte maturity to ultrasound morphology, blood flow and hormone concentrations of the preovulatory follicle in mares.Biol. Reprod. 77, 202-208.

Grazul-Bilska, A.T., Navanukraw, C., Johnson, M.L., Arnold, D.A.,Reynolds, L.P., Redmer, D.A., 2006.Expression of endothelial nitric oxide synthase in the ovine ovary throughout the estrous cycle. Reproduction 132, 579587.

Grazul-Bilska, A.T., Navanukraw, C., Johnson, M.L., Arnold, D.A., Reynolds, L.P., Redmer, D.A., 2006.Expression of endothelial nitric oxide synthase in the ovine ovary throughout the estrous cycle. Reproduction 132, 579587.

Grazul-Bilska, A.T., Navanukraw, C., Johnson, M.L., Vonnahme, K.A., Ford, S.P., Reynolds, L.P.,Redmer, D.A., 2007.Vascularity and expression of angiogenic factors in bovine dominant follicles of the first follicular wave. J. Anim. Sci. 85, 1914-1922.

Greyling, J.P.C., Van Nierkerk, C.H., Grobbe-laar, J.A.N., 1985. Synchronization of oestrus in the Boer goat doe: the response to the use of intravaginal progestagen and PMSG. S. Afr. J. Anim. Sci. 15, 52-55.

Karaca, F., Ataman, M.B., Coyan, K., 2009. Synchronization of estrus with shortand long-term progestagen treatments and the use of GnRH prior to short-term progestagen treatment in ewes. Small Ruminant Res. 81, 185-188.

Karaca, F., Doğruer, G., Sarıbay, M.K., Ateş, C.T., 2010.Oestrus synchronization with short-term and long-term progestagen treatments in goats: the use of GnRH prior to short-term progestagen treatment. J. Ital. Anim. Sci. 9.

Hashemi, M., Safdarian, M., Kafi, M., 2006.Estrous response to synchronization of estrus using different progesterone treatments outside the natural breeding season in ewes. Smal. Rum. Res. 65, 279-283.

Matsui, M., Miyamoto, A., 2009. Evaluation of ovarian blood flow by colour Doppler ultrasound: practical use for reproductive management in the cow. Vet. J. 181, 232240.

Moonmanee, T., Navanukraw, C., Uriyapongson, S., Kraisoon, A., Aiumlamaic, S., Guntaprom, S., Rittirod, T., Borowicz, P.P., Redmer D.A., 2013.Relationships among vasculature, mitotic activity, and endothelial nitric oxide synthase (eNOS) in bovine antral follicles of the first follicular wave. Dome. Anim. Endocrinol. 45, 11-21.

Moonmanee, T., Navanukraw, C., Uriyapongson, S., Kraisoon, A., Aiumlamaic, S., Guntaprom,S.,Rittirod,T., Borowicz,P.P., Redmer D.A., 2013.Relationships among vasculature, mitotic activity, and endothelial nitric oxide synthase (eNOS) in bovine antral follicles of the first follicular wave. Dome. Anim. Endocrinol. 45, 11-21.

Motlomelo, K.C., Greyling, J.P.C., Schwalbach, L.M.J., 2002. Synchronisation of oestrus in goats: the use of different progestagen treatments. Smal.Rum. Res. 45, 45-49.

Noël, B., Bister, J.L., Pierquin, B., Paquay, R., 
1994. Effects of FGA and PMSG on follicular growth and LH secretion in Suffolk ewes.Theriogenology 41, 719-727.

Oliveiraa, M.E.F., Felicianoa, M.A.R., D’Amatoa, C.C., Oliveiraa, L.G., Bicudob, S.D., Fonsecac, J.F., Vicentea, W.R.R., Viscod, E., Bartlewskid, P.M., 2014. Correlations between ovarian follicular blood flow andsuperovulatory responses in ewes. Anim. Reprod.Sci. 144, 30- 37.

Quirk, S.M., Cowan, R.G., Harman, R.M., Hu, C..L., Porter, D.A., 2004. Ovarian follicular growth and atresia: the relationship between cell proliferation and survival. J. Anim. Sci. 82, E40-E52.

Redmer, D.A., Doraiswamy, V., Bortnem, B.J., Fisher, K.,Jablonka-Shariff, A., GrazulBilska,A.T., ReynoldsL.P., 2001. Evidence for a role of capillary pericytes in vascular growth of the developing ovine corpus luteum. Biol. Reprod. 65, 879-889.

Regueiro, M., Clariget, RP.,Ganzábalb, A., Aba, M., Forsberg, M., 1999. Effect of medroxyprogesterone acetate and eCG treatment on the reproductive performance of dairy goats. Small Ruminant Res. 33:223230.

Romano, J.E., 2004. Synchronization of estrus using CIDR, FGA or MAP intravaginal pessaries during the breeding season in $\mathrm{Nu}$ bian goats. Small Ruminant Res. 55, 15-19.

Sim oes, J., Almeida, J.C., Valentim, R., Baril,
G., Azevedo, J.,Fontes, P., Mascarenhas, R., 2006. Follicular dynamics in Serrana goats.Anim. Reprod. Sci. 95, 16-26.

Tamanini, C., Basini, G., Grasselli, F., Tirelli, M., 2003. Nitric oxide and the ovary. J. Anim. Sci. $81,1-7$.

Tessaro, I., Luciano, A.M.,Franciosi, F.,Lodde, V.,Corbani, D., Modin, S.C., 2011.The endothelial nitric oxide synthase/nitric oxide system is involved in the defective quality of bovine oocytes from low mid-antral follicle count ovaries. J. Anim. Sci. 89, 2389-2396.

Ustuner, B., Gunay, U., Nur, Z., Ustuner, H., 2007. Effects of long and short-term progestagen treatments combined with PMSG on oestrus synchronization and fertility in Awassi ewes during the breeding season. Acta. Vet. Brno. 76, 391-397.

Van den Hurk, R., Zhao, J., 2005.Formation of mammalian oocytes and their growth differentiation and maturation within ovarian follicles. Theriogenology 63, 1717-1751.

Whitley, N.C., Jackson, D.J., 2004. An update on estrus synchronization in goats: A minor species. J. Anim. Sci. 82 (Suppl. E.), 270276.

Witt, M.C., Bollwein, H., Probst, J., Baackmann, C., Squires, E.L., Sieme, H., 2012. Doppler sonography of the uterine and ovarian arteries during a superovulatory program in horses. Theriogenology 77, 1406-1414.

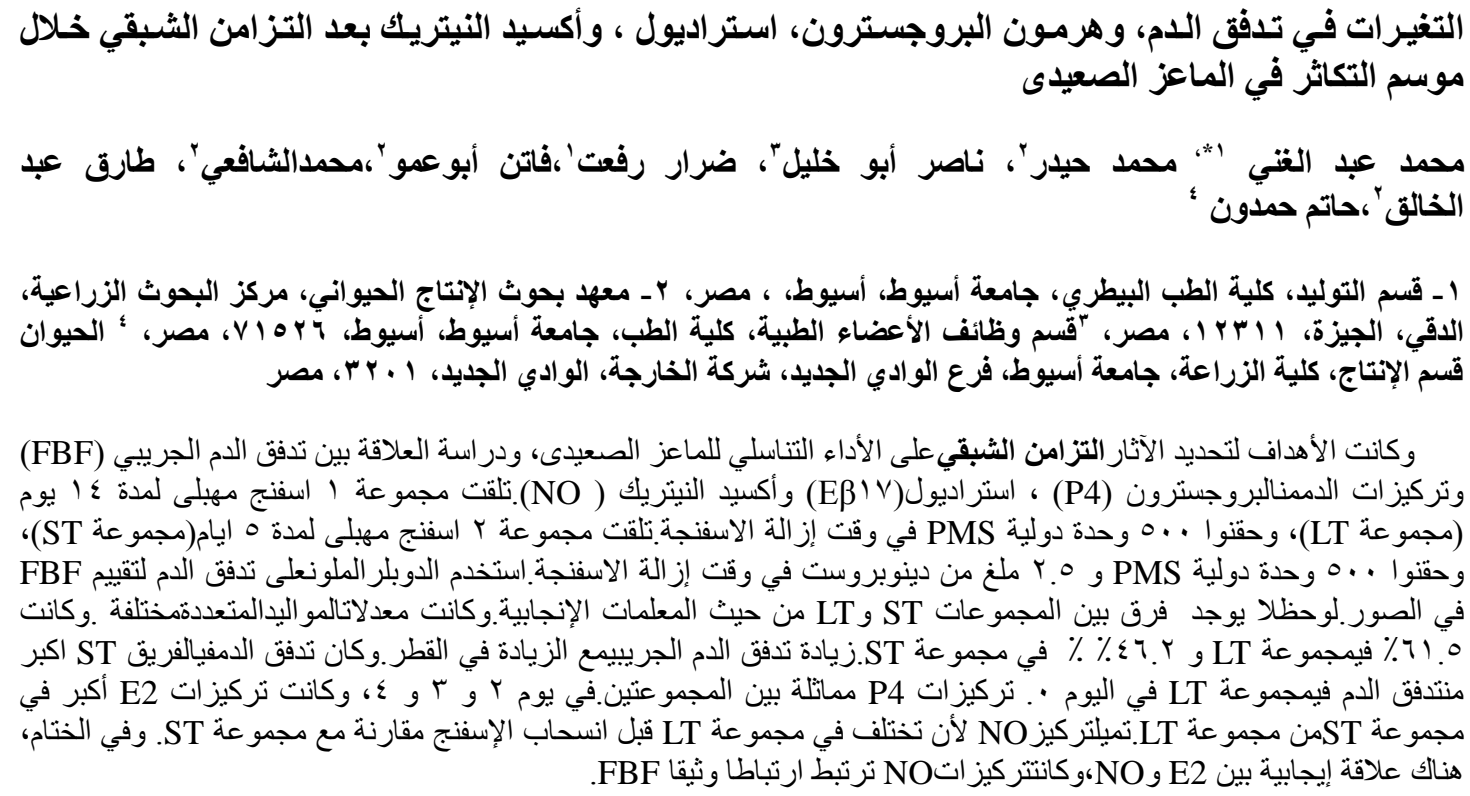

